\title{
The Logic of Representation in Political Rituals
}

\author{
Ragnar M. Bergem \\ Faculty of Theology, University of Cambridge, United Kingdom
}

Political rituals, like the sovereign acclamation described in Rousseau's social contract,
exhibit a logic of representation that seem to oscillate between presence and absence,
and enact a problematic identification of the people as a multitude of individuals and as
a whole. This article explores this logic of rituals by comparing problems of political
representation in Rousseau and Agamben with the highest principle of Aristotle's
philosophy. It thus elucidates the problem of representation in rituals of political power.

Keywords: representation, power, ritual, Agamben, Rousseau, Aristotle

\section{Introduction}

It would seem that representation is impossible. On a very basic level, it entails a paradoxical simultaneity, denoting a moment when something that is absent is rendered present while remaining absent. In political philosophy, the problem has notably been formulated by Hanna Fenichel Pitkin's The Concept of Political Representation. ${ }^{1}$ Pitkin notes that the problem of representation as the simultaneity of presence and absence is, in a political context, a novel concept which only arises in late mediaeval and modern times. The earliest uses of the term for the representation of one person by another in a political institution is in the thirteenth and fourteenth centuries. The Romans used the word representare, but this concept had a temporal frame which denoted the transition from absence to presence, and thus avoided any trace of a coincidentia oppositorum of presence and absence. ${ }^{2}$ Such a frame, be it temporal or spatial, is necessary for us to represent the concept of representation, yet the absence represented in the temporal or spatial gap between the thing and the representation only grasps one part of the concept. For representation also includes a notion of repetition or substitution, which demands some account of the presence of that which has been made absent. The coincidence of these poles, of presence and absence, being and non-being, seem to make representation impossible, and this impossibility invites thought. 
In this article, I will relate this transition from absence to presence to the notion of manifestation, and thus to the Greek word doxa, in the sense of 'seeming', 'appearing', even 'glory'. Common to these political and philosophical notions of representation is a concern with power and its legitimacy. These is something like a mutual dependence between representation and power so that, according to Louis Marin, in rituals of representation 'power appropriates representation as its own', and representation 'produces its power and produces itself as power. ${ }^{3}$ For representation has the double effect of rendering present and constituting a subject for whom the representation is legitimate or authoritative. Rituals in political and theological varieties achieve a result that seems impossible yet is crucial for the continuation or institution of power.

I will therefore explore the paradox of representation by arranging a constellation of political, theological and metaphysical questions in their relation to rituals. There are, I believe, significant analogies between the parts of this constellation, and by comparing them, we will come to see what is at stake in the question of representation. The essay should therefore not be taken as a tracing a kind genealogy, but rather, in a somewhat Platonist fashion, tracing analogous representations of the soul, the sacred and the city, and pushing them dialectically to their limit. I will not present an answer to the question of representation, but rather, in asking it, acknowledge that comprehending the question is essential to, though not strictly identical with, answering it. If we understand the impossibility of representation, perhaps we see how it nonetheless might be possible.

I will proceed in three steps, relating forms of thought, questions and problems that surface in various thinkers. First, I will show how, in the context of the political theory of Jean-Jacques Rousseau, the notion of the general will as the sovereign is built on an aporetic identification of the people as individuals and as a whole. It is, I suggest, the consequence of this aporetic identification that representation of sovereignty is denied. For Rousseau, then, the sovereign must be wholly present - there is not un point de milieu between absence and presence. The transaction of power takes place in a political ritual of acclamation in which there is no distinction between the people as a multitude and a united body, and where the body is rendered wholly present. Secondly, moving on to the Italian philosopher, Giorgio Agamben's considerations of political liturgies and rituals, I argue that Rousseau's conception of pure presence of political will in the assembly becomes one case in point of the appearance of glory in political liturgies. For Agamben, glory is an appearing which has constantly to be 
produced in order to mediate what cannot be mediated. He suggests that the glory of political liturgies - their representation - is there to capture and to hide the failed mediation of presence and absence in political representation. Thirdly, and finally, I will compare this glory to another kind of doxa. Aristotle's configuration of the principle of non-contradiction, which he calls 'the most indisputable of all doxa', seemingly confirms Agamben's analysis that doxa stands in for an absence of mediation. ${ }^{4}$ The principle covers the gap between the all and the whole in Aristotle's metaphysics, and is thus structurally akin to Rousseau's problem of sovereign representation. For Aristotle, one might say, the principle of non-contradiction represents a convergence or mediation of the all and the whole that is ultimately not there. Our circuitous route elucidates the logic of representation in rituals of power. We find in the end a transaction between representation and power whose very condition is a contradiction: there is an oscillation between absence and presence, and an abstract identification of the One with the Many.

\section{The Presence of the General Will}

In the sixth chapter of the first book of the Social Contract, Jean-Jacques Rousseau reduces the principle of the social contract to its naked form:

Each of us puts his person and all his power in common under the supreme direction of the general will; and in a body we receive each member as an indivisible part of the whole. ${ }^{5}$

Although this negotiation may be regarded as Rousseau's fundamental take on the political question, its form and its perplexing character are by no means unique. At issue is a fundamental transaction of power between the people and the people, between every one and everyone, built on a novel anthropology that relates self-love (amour propre) and sympathy (pitié). Self-love can, albeit through a difficult integration with sympathy as well as other passions and virtues, be employed for collective and political purposes. ${ }^{6}$ Giving oneself over to the general will is tantamount to giving oneself to oneself. Each individual suspends their individual power and hands it over to the general will, which subsequently governs everyone with supreme power. The transaction is not between the people and a sovereign, but between individuals and themselves. The result is a curious relation, an apparent vice passing for virtue in Rousseau's political theory: 
[E] ach individual, contracting with himself so to speak, finds that he is double engaged [engagé = committed, bound], namely toward private individuals as a member of the sovereign and towards the sovereign as a member of the State. ${ }^{7}$

Rousseau's political vision seeks to ensure the autonomy of every citizen by postulating a social contract that establishes the voulonté generale, which, due to its being the will of no body in particular, becomes the will of all.

As Patrick Riley has argued, the term 'general will' originates in theological discussions theologians about God's election of his people, taken up by French thinkers such as Blaise Pascal, Nicolas Malebranche, Pierre Bayle and Charles Montesquieu. ${ }^{8}$ In the mediaeval theological tradition, there was an ongoing debate of St. Paul's claim in the letter to Timothy that 'all men will to be saved' (1 Tim 2:4). The apostle's claim leads to an inescapable discussion of the balance between universal and particular salvation, and poses a question which could be reformulated as a question about the representation of the body of the church. If God willed all men to be saved, how could one account for the fact that not all were in fact saved? That is, how does one mediate between the unlimited election of all and the election of those who are saved? The dilemma was dealt with in roughly two ways: the Augustinian solution was to deflate the meaning of 'all', taking it to mean 'all kinds of people', whereas the Thomistic way was to bring about a sort of split within God's will between his general and weaker will to save everyone, and his particular will to save those he does in fact save. ${ }^{9}$ The character of this voulonté generale is strange indeed, because 'everyone' here cannot mean each and every one in particular-it must refer to the will to save a wholly abstract 'all' which refers neither to the sum of all created human beings, nor to anyone in particular. The theological residue in Rousseau is a concept that occupies 'a place midway between particularity and universality', which designates neither each and every one, nor anyone in particular. ${ }^{10}$

The political transaction is perplexing, but it secures the result sought by Rousseau. Autonomy is the situation of being bound doubly, as sovereign and subject, directing the people for the people, being directed by the people as the people. ${ }^{11}$ This autonomy, however, comes at the cost of creating a persisting tension between the individual with his or her own interests who comes together with others to create a body politic to protect and promote these interests, and the new man, the citizen that is constructed, transformed and shaped according to a particular civic pattern. According to John M. Warner, the 'sense one has of himself as himself is obscured by the comprehensive way in which he identifies with the social 
institutions that constitute his personhood. ${ }^{12}$ Supposedly integrated with and sustaining the body politic, the individual is split into two - there can ultimately be "no stable solution to the tension between love of self and love of society. ${ }^{, 13}$

The general will or the body politic in its passive capacity is the state; in its active capacity, it is the sovereign. The most pressing questions are, however, the following: if the body politic is the point of convergence between individuals and the people as a whole, what kind of body is this? Where is it placed? How is it rendered present? Can it be represented? No!, objects Rousseau. Sovereignty 'being only the exercise of the general will, can never be alienated, and [...] the sovereign, which is only a collective being, can only be represented by itself. ${ }^{14}$

The representation of the sovereign can only occur by and through itself, in such a way that the distance, alienation and absence implied by representation is effaced, transforming representation into presence. Either the sovereign is itself, 'or it is something else; there is no middle ground [point de milieu]. ${ }^{15}$ Whereas government, as power, can be transmitted, transacted, alienated and represented, the sovereign as will cannot.

In the exercise of sovereign power in its legislative function, the people must be physically and temporally present. According to Rousseau, that is why the English people although they considered themselves free, were only so 'during the election of the members of Parliament', and it is apposite that they should be slaves the rest of the time, since they do not realise the significance of that single moment of freedom. ${ }^{16}$ Having representing members of parliament does not amount to freedom — quite the opposite. Instead, the moment of election itself is how the will is rendered present and each individual finds his will being a member of the general will. The assembly is therefore the true place of the sovereign action, where the people as individuals together choose for the people as a whole.

\section{Glory and Acclamation}

In his book The Kingdom and the Glory: for a theological genealogy of economy and government, Giorgio Agamben stages a sort of resurrection of the conversation between Erik Peterson and Carl Schmitt in which he excavates the economic paradigm dominating the Western theo-political tradition. In the seventh chapter, Agamben hones in on the concept of glory and the ways in which it has been suppressed and mistreated by both Peterson and Schmitt. Drawing also on the political philosophy of Ernst Kantorowicz and others, he attends to the liturgies of political power, the rituals and ceremonies in which glory, a concept full of 
theological implications and presuppositions, is bestowed upon political power.

Agamben's discussion focuses on the liturgical and juridical role of acclamation in the context of political power. An acclamation 'is an exclamation of praise, of triumph, of laudation or of disapproval yelled by a crowd in determinate circumstances,' often happening at the entrance of the king to a city, to magistrates or emperors, 'ritually repeated' and modulated. ${ }^{17}$ These verbal and physical gestures were not innocent of political or juridical meaning, but could, for example, 'act as a substitute for the vote of individual voters. ${ }^{18}$ But acclamation should not be taken simply as an alternative electoral procedure, as that would blind us to their peculiar function, as emphasised by Schmitt. Individual voting in democracies encourages secrecy or invisible transactions of power. But visibility is a highly prioritized value in politics, and the dis-appearance of power veils the question of who makes the political decision. In contrast to the invisibility of the ballot, and following Rousseau, Schmitt locates in acclamation 'the real activity, capacity, and function of the people'. ${ }^{19}$ Whereas a secret ballot veils the constituting power of the nation, acclamation makes sovereignty public and present. Beyond representation and stronger than mere manifestation, the moment of acclamation is the sovereign as such. The moment and place of acclamation simply is the body politic in its active capacity.

Agamben's archaeology of ceremonies of power, such as theological liturgies, Roman political rituals, royal vestures, can be put in the following terms. ${ }^{20}$ If we allow ourselves to consider these ceremonies of power in terms of Hans Christian Andersen's tale 'The Emperor's New Clothes', one observes that the striking feature of the emperor's new clothes is precisely that they are not fit for an emperor. To be sure, the people's fear of the emperor prevents them from pointing out this obvious fact. Yet, the visibility of his royal garments is the essential thing. An emperor with no clothes is no emperor at all, and any frank child will surely make that clear to the rest of us. Some sort of representation, or even a collective behaviour 'as if' he had clothes, would not suffice in the long run. The clothes do not express his rank, they constitute it through their production of glory, because 'imperial sovereignty is, in its very behaviour, in its gestures as its apparel' ${ }^{21}$

The gestures, vestures and ritual acclamations are performative utterances that establish what they denote. They do not represent, they present, and thereby create a kind of threshold between language and action, or law and reality, liturgy and power. This space is precisely what Agamben calls 'glory'; it is 'the uncertain zone in which acclamations, ceremonies, liturgies, and insignia operate'. ${ }^{22}$ For Agamben, this liminal zone of political 
liturgies demonstrates the interconnection or indistinction between the power of politics and the economy of theology. Agamben's archaeology of the theology of glory which he sees at work in political liturgies is, despite its dense character, quite straightforward: glory and glorification arise at points of mediation between the immanent and the transcendent; between Trinitarian economy and immanence, between the administration of Government and the sovereignty of the Kingdom, between the real acts of individuals and the power of the general will, and so on. Glory is what sustains and mediates these polar terms. Yet Agamben is not himself handing out praise at this point: for him, glory steps in to mediate as a presence that dazzles, muddles and distracts us from what is taking place, from the indistinction between transcendence and immanence that is being produced and re-produced. Glory seemingly denotes a realm of pure presence within which the transcendent and the immanent are mediation, but which actually is an absence and thus a place broken mediation. The invocation of pure presence can therefore, if manipulated and understood rightly, be challenged. In this case, it will reveal an absence, or rather an indistinction between, but not a surpassing of, presence and absence. In the moment of acclamation, the general will is supposedly present, but if one escapes the impression of glory, one comes to see that it is equally absent. For Agamben, the glorious gesture of political liturgy is a sleight of hand. This zone of indistinction where general will is one with the people, where the King's eternal and mortal bodies unite, is in fact empty.

\section{The Most Indisputable of All Beliefs}

In what follows, I will draw a connection between the doxa which Agamben seeks to describe, which is present or which presents the sovereign as the perplexing identity of immanence and transcendence, or the negotiation of the one and the many in political liturgies, and the linchpin of Aristotle's metaphysics, the principle of non-contradiction. I do not thereby mean to demonstrate that 'Aristotle actually bequeathed the paradigm of sovereignty to Western philosophy', as Agamben claimed to have done in relation to Aristotle's ontology of potentiality and actuality, but only to explore in a preliminary manner analogies between metaphysical and political forms of thought. ${ }^{23}$

Aristotle's conception of science is based on a rejection of the dimension of Plato's philosophy that seeks to make dialectic the justification for knowledge. For Aristotle, dialectic can only achieve a coherence among beliefs, not an epistemic justification, which means that 
every discipline must have its justification in a separate intuition of its highest genus. ${ }^{24}$ As he indicates in the Posterior Analytic, 'one cannot demonstrate the proper principles of anything; for those will be principles of everything, and understanding of them will be sovereign over everything, 25

However, Aristotelian science has no highest science if by that one means a single genus which includes all other genera, and there is no immediate, intuited knowledge of the whole of reality. ${ }^{26}$ When the unity of knowledge cannot be grounded in the intuition of the Whole, it must be secured by the principle of non-contradiction. This principle, however, is a doxa, a belief, opinion or appearance. The principle which he calls the 'most indisputable of all beliefs [bebaiotate doxa pason]' serves, in the words of Stanley Rosen, 'in place of an unavailable cognitive conception of the wholeness or unity of beings' ${ }^{27}$ Aristotle tries to justify this most certain opinion without recourse to dialectic or intuition by making an argument to the effect that the denial of the principle of non-contradiction assumes its affirmation. This novel use of the dialectic has lead commentators to suggest Aristotle is proposing a different conception of science than that laid out in the Analytics. ${ }^{28}$ This quasidialectical argument nonetheless assumes the principle of non-contradiction for it to be persuasive and can only show that someone denying the principle will also affirm it, an objection which carries no weight for the one who is already content with holding contradictory positions. ${ }^{29}$ Even if Aristotle is able to show that the denial of the principle entails the destruction of significant speech and the dispersion of essence into accidents, this does not amount to a demonstration in the strict sense. ${ }^{30}$

The principle of non-contradiction is the condition for the unity of science, but presumes the illegitimate identification of the All and the Whole. When the world cannot be united by a single cognition, which means that it threatens to disperse into wholly separate domains, or 'sciences', it must be brought back to unity by a law that represents the abstract identity the All and the Whole.

But this identity of the All and the Whole is contradictory. If one assumes that the Whole is the sum of the All, then one is forced to equate the One and the Many, since the unity of the Whole, its oneness, is supposed to be identical with its many parts, which form the sum of the All. ${ }^{31}$ This is tantamount to saying that the One is not One, but rather that it is Many. The Whole must therefore be different from the All, which is equally problematic, since the All is nothing but the sum of the Whole. If the All and the Whole are not identical, some third thing, not included in the All, would have to be added to the Whole; but then the All is not the All any longer, as at least one thing is excluded from it. In other terms, any 
formal monad or whole must be the sum of its part, yet some third term is always needed to make this set of parts the parts of this whole. This third term or relation is contradictory, as it would have to be and not be both Whole and All.

Now, if the principle of non-contradiction stands in for the identity of the All and the Whole, could we say that this designates the same doxa discussed above? In each case, the sovereign principle stands in for the contradiction it cannot resolve. Rousseau's sovereign, the voulonté generale, is exactly the point of identity between the people as a number of individuals and the people as a unified whole. This sovereign moment, like the principle of non-contradiction, is the condition for lawfulness, it is the law of laws: the sovereign is the one who prevents conflict and contradiction in the city by establishing and upholding the law, just as the understanding of the first principles in Aristotle, as we saw above, is 'sovereign over everything'.

What I would like to suggest, then, is that one could find a relation between these two glories through the choice by which they are united, and that this choice relates to the question of representation and rituals of presence. When one discovers the aporia of the All and the Whole, law steps in, something akin to the law of non-contradiction.

This forces upon us the following choice: first, one tries to represent the sovereign. One might think of the well-known frontispiece of Thomas Hobbes' Leviathan, by Abraham Bosse (1651): here the sovereign hovers over the city, his body being made up of miniature versions of its members, their multitude fitting exactly into the shape of the sovereign body. It seeks to represent the negotiation of the people as a number of unique individuals forming a coherent unity, illustrating Hobbes' theory, "[a] multitude of men are made one person, when they are by one man, or one person, represented; so that it be done with the consent of every one of that multitude in particular" (reference: Hobbes, Leviathan, I.16.13).

There are two things to note about this representation: first, its content is contradictory; it is simply the spatial dimension of the representation which mediates the contradiction between the All and the Whole. If, however, one takes space to be a medium of externality, this representation does not solve the conceptual problem. But, secondly, and more importantly, it is an equivocal representation, a representation of a pure absence, since the sovereign as this point of convergence is strictly speaking nowhere, and has no real body. Rather, a particular kind of representation is doing the work of the law of non-contradiction: it sustains the fiction that there is a unity among the members of the city.

These representations function, as the Neo-Kantian philosopher Hans Vaihinger has noted, 'as if' they referred to a real unity. ${ }^{32}$ If calling them 'useful fictions' would devalue 
them or underestimate their importance, one could perhaps name them 'crucial fictions', or foundational myths.

However, this kind of formalism faces a common objection: the representation is transcendentally justified, i.e., it is taken as that representation which one would need to presuppose if one had real unity of knowledge, action or community. It serves regulative and pragmatic functions, and implies a diremption of politics and ontology, between what is procedurally and pragmatically necessary and ontologically the case. The fear, then, is that such representations are put in place to obscure the fact that we have no unity, that there is no sovereign, that there is a gap which we are trying to veil. Soon we begin to suspect that this sovereign, as well as the laws secured by it, are forced upon us and are at best grounded in the fear of insecurity or anarchy.

If representation ultimately implies an absence and leaves us with a regulative idea without real justification, there is the alternative of pure presence. This is really what Agamben tries to analyse in The Kingdom and the Glory. Although representation is out of the question in these rituals, the attempt to identify law and power, or the people and the general will, seeks to achieve the same effect: to traverse the gap and shortcut negotiation. The acclamation by the people when it is gathered produces a sovereign will. In these rituals, it is not simply the case that they have to perform what they denote- the performance and the utterance have to be one and the same thing. Now, Agamben's point is that this presence is likewise an absence, for it is posited, but cannot be understood, it cannot be made sense of. All it does is to dazzle us with glory in order to prevent us from seeing what is missing.

\section{Conclusion}

I will end with the same problem with which I began: What would it take to represent without thereby implying an absence? It seems that a discussion of the possibility of representation would have to reconsider the place and character of sovereign principles, that is, of lawupholding principles which stand in for a real negotiation of the All and the Whole. From the perspective of political rituals and liturgies, it leads to the question of the possibility of mediation - whether there is any sense in which rituals can mediate, not simply produce glory in place of, or as a way of capturing and hiding the aporia that separates and collapses the bodies of individuals and the political body. Is there, in other words, a gesture, an acclamation or even public deliberation, that negotiates between the All and the Whole, between the individual and the city, and therefore also mediates between presence and absence? Could 
there be a form of clothing — of what fashion I know not — that would represent, without thereby merely imposing power? If not, I suspect, the emperor might be naked after all.

\section{Bibliography}

Agamben, Giorgio. Homo Sacer. Sovereign Power and Bare Life. Meridian. Stanford, Calif: Stanford University Press, 1998.

- The Kingdom and the Glory: For a Theological Genealogy of Economy and Government / (Homo Sacer II, 2). Meridian, Crossing Aesthetics. Stanford, California: Stanford University Press, 2011.

Agamben, Giorgio, Lorenzo Chiesa, and Matteo Mandarini. The Kingdom and the Glory: For a Theological Genealogy of Economy and Government. Homo Sacer, II, 2. Stanford, California: Stanford University Press, 2011.

Aristotle. 'Metaphysics'. In The Complete Works of Aristotle: The Revised Oxford Translation, edited by Jonathan Barnes. Bollingen Series, 71:2. Princeton, N.J: Princeton University Press, 1984.

—. 'Posterior Analytics'. In The Complete Works of Aristotle: The Revised Oxford Translation, edited by Jonathan Barnes. Bollingen Series, 71:2. Princeton, N.J: Princeton University Press, 1984.

Bolton, Robert. 'Aristotle's Conception of Metaphysics as a Science'. In Unity, Identity, and Explanation in Aristotle's Metaphysics, edited by T. Scaltsas, David Charles, and Mary Louise Gill, 321-54. Oxford : Oxford ; New York: Clarendon Press ; Oxford University Press, 1994.

Cohen, Joshua. Rousseau: A Free Community of Equals. Founders of Modern Political and Social Thought. New York: Oxford University Press, 2010.

Hasan, Rafeeq. 'Autonomy and Happiness in Rousseau's Justification of the State'. The Review of Politics 78, no. 03 (2016): 391-417. doi:10.1017/S0034670516000267.

Irwin, Terence. Aristotle's First Principles. Repr. Oxford: Clarendon Press, 2002.

Marin, Louis. Portrait of the King. Basingstoke: Macmillan, 1988.

Neuhouser, Frederick. Foundations of Hegel's Social Theory: Actualizing Freedom.

Cambridge, Mass.: Harvard University Press, 2000.

http://public.eblib.com/choice/publicfullrecord.aspx?p=3300348.

Pennock, J. Roland, and John W. Chapman, eds. Representation. Nomos, X. New York: Atherton Press, 1968. 
Pitkin, Hanna Fenichel. The Concept of Representation. 1. paperback ed., [Nachdr.].

Berkeley, Calif.: Univ. of California Press, 20.

Riley, Patrick. The General Will before Rousseau: The Transformation of the Divine into the

Civic. Princeton: Princeton University Press, 2014.

Rosen, Stanley. G. W. F. Hegel; an Introduction to the Science of Wisdom. New Haven: Yale University Press, 1974.

Rousseau, Jean-Jacques, Roger D. Masters, and Judith R. Masters. On the Social Contract:

With Geneva Manuscript and Political Economy. New York: St. Martin's Press, 1978.

Rousseau, Jean-Jacques, and Raymond Trousson. Euvres complètes. Éd. thématique du tricentenaire. Genève: Éd. Slatkine [u.a.], 2012.

Runciman, David. 'The Paradox of Political Representation'. Journal of Political Philosophy 15, no. 1 (2007): 93-114.

Schmitt, Carl. Volksentscheid Und Volksbegehren : Ein Beitrag Zur Auslegung Der Weimarer Verfassung Und Zur Lehre von Der Unmittelbaren Demokratie Ant. Berlin: De Gruyter, 1927. Vaihinger, Hans, and C.K. Ogden. The Philosophy of 'As If'. London: Kegan Paul, Trench, Trubner \& Co, 1935.

Warner, John M. Rousseau and the Problem of Human Relations. University Park, Pennsylvania: The Pennsylvania State University Press, 2015.

\section{Notes on the contributor}

Ragnar M. Bergem is a PhD student in Theology \& Religious studies at the Faculty of Divinity, University of Cambridge. His research considers the problem of judgement in modern philosophical and political thought from the perspective of political theology.

\section{Notes}

${ }^{1}$ Hanna Fenichel Pitkin, The Concept of Representation, 1. paperback ed., [Nachdr.] (Berkeley, Calif.: Univ. of California Press, 20). See also J. Roland Pennock and John W. Chapman, eds., Representation, Nomos, X (New York: Atherton Press, 1968); David Runciman, 'The Paradox of Political Representation', Journal of Political Philosophy 15, no. 1 (2007): 93-114.

${ }^{2}$ Pitkin, The Concept of Representation, 3.

${ }^{3}$ Louis Marin, Portrait of the King (Basingstoke: Macmillan, 1988), 4-5.

${ }^{4}$ Aristotle, 'Metaphysics', in The Complete Works of Aristotle: The Revised Oxford Translation, ed. Jonathan Barnes, Bollingen Series, 71:2 (Princeton, N.J: Princeton University Press, 1984), 1011b135. 
${ }^{5}$ Jean-Jacques Rousseau and Raymond Trousson, CEuvres complètes, Éd. thématique du tricentenaire (Genève: Éd. Slatkine [u.a.], 2012), V, 479; Translation from: Jean-Jacques Rousseau, Roger D. Masters, and Judith R. Masters, On the Social Contract: With Geneva Manuscript and Political Economy (New York: St. Martin's Press, 1978), 53.

${ }^{6}$ John M. Warner, Rousseau and the Problem of Human Relations (University Park, Pennsylvania:

The Pennsylvania State University Press, 2015), 60-86, 187-215.

${ }^{7}$ Rousseau and Trousson, Euvres complètes, V, 480; Rousseau, Masters, and Masters, On the Social Contract, 54.

${ }^{8}$ Patrick Riley, The General Will before Rousseau: The Transformation of the Divine into the Civic (Princeton: Princeton University Press, 2014).

${ }^{9}$ Riley, The General Will before Rousseau: The Transformation of the Divine into the Civic, 4.

${ }^{10}$ Riley, The General Will before Rousseau: The Transformation of the Divine into the Civic, xii.

${ }^{11}$ For the autonomy interpretation of Rousseau, see Frederick Neuhouser, Foundations of Hegel's Social Theory: Actualizing Freedom (Cambridge, Mass.: Harvard University Press, 2000), 5581, http://public.eblib.com/choice/publicfullrecord.aspx?p=3300348; Joshua Cohen, Rousseau: A Free Community of Equals, Founders of Modern Political and Social Thought (New York: Oxford University Press, 2010). But see also Raqeef Hasan's argument that social autonomy accounts of Rousseau tend to underplay the importance of the teleological aspect of social autonomy in his thought: autonomy is simply not a question of formal legitimacy based on the criterion of self-legislation, and happiness is not only politically relevant as a question of the stability of the community. Rafeeq Hasan, 'Autonomy and Happiness in Rousseau's Justification of the State', The Review of Politics 78, no. 03 (2016): 391-417, doi:10.1017/S0034670516000267.

${ }^{12}$ Warner, Rousseau and the Problem of Human Relations, 213.

${ }^{13}$ Warner, Rousseau and the Problem of Human Relations, 215.

${ }^{14}$ Rousseau and Trousson, Euvres complètes, V, 489. Rousseau, Masters, and Masters, On the Social Contract, 59.

${ }^{15}$ Rousseau and Trousson, Euvres complètes, V, 566; Rousseau, Masters, and Masters, On the Social Contract, 102.

${ }^{16}$ Rousseau and Trousson, Euvres complètes, 566; Rousseau, Masters, and Masters, On the Social Contract, 102.

${ }^{17}$ Carl Schmitt, Volksentscheid Und Volksbegehren : Ein Beitrag Zur Auslegung Der Weimarer Verfassung Und Zur Lehre von Der Unmittelbaren Demokratie Ant (Berlin: De Gruyter, 1927), 33-34. Translated and cited in Giorgio Agamben, The Kingdom and the Glory: For a Theological Genealogy of Economy and Government / (Homo Sacer II, 2), Meridian, Crossing Aesthetics (Stanford, California: Stanford University Press, 2011), 169.

${ }^{18}$ Agamben, The Kingdom and the Glory, 170.

${ }^{19}$ Agamben, The Kingdom and the Glory, 171.

${ }^{20}$ Giorgio Agamben, Lorenzo Chiesa, and Matteo Mandarini, The Kingdom and the Glory: For a Theological Genealogy of Economy and Government, Homo Sacer, II, 2 (Stanford, California: Stanford University Press, 2011), 167-96.

${ }^{21}$ Agamben, The Kingdom and the Glory, 178.

${ }^{22}$ Agamben, The Kingdom and the Glory, 188.

${ }^{23}$ Giorgio Agamben, Homo Sacer. Sovereign Power and Bare Life, Meridian (Stanford, Calif: Stanford University Press, 1998), 46.

${ }^{24}$ Terence Irwin, Aristotle's First Principles, Repr (Oxford: Clarendon Press, 2002), 137-41.

${ }^{25}$ Aristotle, 'Posterior Analytics', in The Complete Works of Aristotle: The Revised Oxford Translation, ed. Jonathan Barnes, Bollingen Series, 71:2 (Princeton, N.J: Princeton University Press, 1984), 76a16-18.

${ }^{26}$ Stanley Rosen, G. W. F. Hegel; an Introduction to the Science of Wisdom (New Haven: Yale University Press, 1974), 82. 
${ }^{27}$ Aristotle, 'Metaphysics', 1011b13-5. Rosen, G. W. F. Hegel; an Introduction to the Science of Wisdom, 70.

${ }^{28}$ Robert Bolton, 'Aristotle's Conception of Metaphysics as a Science', in Unity, Identity, and Explanation in Aristotle's Metaphysics, ed. T. Scaltsas, David Charles, and Mary Louise Gill (Oxford : Oxford ; New York: Clarendon Press ; Oxford University Press, 1994), 322.

${ }^{29}$ Irwin, Aristotle's First Principles, 181-89.

${ }^{30}$ Aristotle, 'Metaphysics', 1007a21-36.

${ }^{31}$ Rosen, G. W. F. Hegel; an Introduction to the Science of Wisdom, 89.

${ }^{32}$ Hans Vaihinger and C.K. Ogden, The Philosophy of 'As If' (London: Kegan Paul, Trench, Trubner $\&$ Co, 1935). 